\title{
NEW RECORDS OF THE VIVIPAROUS LIZARD ZOOTOCA VIVIPARA (LICHTENSTEIN, 1823), FROM MACELJ MOUNTAIN, THE NORTHERNMOST PART OF ITS DISTRIBUTION RANGE IN CROATIA
}

\author{
Boris LaUš \\ Croatian Herpetological Society - Hyla, Lipovac I/7, HR10000 Zagreb, Croatia \\ (boris.laus.pmf@gmail.com)
}

Lauš, B.: New records of the Viviparous Lizard Zootoca vivipara (Lichtenstein, 1823) from Macelj Mountain, the northernmost part of its distribution range in Croatia. Nat. Croat., Vol. 25, No. 1, 151-154, 2016, Zagreb

During research of the amphibians and reptiles of Krapina-Zagorje County, several individuals of the Viviparous Lizard, Zootoca vivipara, were recorded at two locations on Macelj Mountain for the first time. The closest known record in Croatia is Žumberak Mountain, approximately $70 \mathrm{~km}$ to the southwest. The new records represent the first data about this species in the Hrvatsko Zagorje region, expanding the known distribution range towards the north. New records are important to better understand the distribution and habitat requirements of this species, since it is listed as data deficient (DD) in the Red Book of amphibians and reptiles of Croatia.

Key words: Zootoca vivipara, distribution, Croatia, Macelj

Lauš, B.: Novi nalazi živorodne gušterice Zootoca vivipara (Lichtenstein, 1823) na Maceljskoj gori, najsjevernijem području njene rasprostranjenosti u Hrvatskoj. Nat. Croat., Vol. 25, No. 1, 151-154, 2016, Zagreb

Tokom istraživanja vodozemaca i gmazova Krapinsko-zagorske županije zabilježeno je nekoliko jedinki živorodne gušterice, Zootoca vivipara, po prvi puta na Maceljskoj gori. Najbliža poznata populacija u Hrvatskoj nalazi se na Žumberačkoj gori, oko $70 \mathrm{~km}$ prema jugozapadu. Novi nalazi predstavljaju prve podatke o ovoj vrsti u Hrvatskom zagorju te pomiču poznatu distribuciju prema sjeveru. Ovi nalazi su važni za bolje razumijevanje distribucije i preferencije staništa ove vrste, koja je klasificirana kao vrsta s nedovoljno podataka (DD) u Crvenoj knjizi vodozemaca i gmazova Hrvatske.

Ključne riječi: Zootoca vivipara, distribucija, Hrvatska, Macelj

The viviparous lizard, Zootoca vivipara, is extremely widespread, its territory ranging from Europe, across most of northern Asia to China and Japan (AgAsYAN et al., 2010). It has both oviparous and viviparous populations. The viviparous populations are widely distributed in the greatest part of its distribution range (from central France and the British Isles up to Scandinavia and eastern Russia) (Heulin et al., 2000). Some oviparous populations exist on the southern margin of this species range, from southern France and northern Spain, southern Austria, Slovenia and Croatia (Heulin et al., 2000) and in the area of northern Italy (CORNETTI et al., 2014). Populations of Z. vivipara are very poorly explored in Croatia, even though there are several literature records ranging from 1854 to 2012 (Jelić, 2014). Distribution details for Croatia are available in Jelić et al., (2012), and in an unpublished graduate thesis (BAŠKIERA, 2013). The species has been confirmed 
so far in four separate areas: Mt Velebit and Gorski Kotar (Kapela, Risnjak and Snježnik Mountains to Plitvice Lakes) in the northwest, the inland mountains of Žumberak to the west, Mt Papuk toward the east, and the low land parts of eastern Croatia (area of Đakovo, Vinkovci, Trpinja and Spačva Forest). Reproductive traits for this species were studied at just two locations in Croatia: the lowland population in Spačva Forest in the east of Croatia (BAŠKIERA \& JeLIĆ, 2013) and the mountain population from the Lakes of Plitvice (Heulin et al., 2000). Both populations turned out to be oviparous.

This species inhabits a variety of different habitats, from the coast to the mountains. By far the most populations are well adapted to temperate and cool climates by their chiefly ovoviviparous mode of reproduction (Dely \& BöHME, 1984). The Macelj Mountain range has such cooler conditions, differing from the surrounding area, due to its characteristics. It is a mountainous area between Croatia and Slovenia, consisting of the mountains Donačka (in Slovenia, $884 \mathrm{~m}$ a.s.l.), Macelj (in Slovenia and Croatia, $718 \mathrm{~m}$ a.s.l.) and Ravna gora (Croatia, $686 \mathrm{~m}$ a.s.l.). This range is the headwater area of several rivers such as the Sutla, Bednja and Krapinica (Anonymous, 2015a). The Macelj Mountain range belongs to the Lower Miocene and consists mostly of sandstone (Macelj sandstone) (TADEJ et al., 1997). Because the sandstone is more resistant to erosion, the area is characterised by sharp and steep ridges on one side and deep trenches on the other. The study area lies in the largest forest complex in northern Croatia and belongs to the Central European flora region (CEROVEČKI, 2002). Most of it is covered with forests of oak, beech or mixed beech-fir (ANONYMous, 2015b).

Surveys of Z. vivipara focused on the Croatian part of Macelj Mountain were carried on from the $24^{\text {th }}$ to the $26^{\text {th }}$ of September, 2011. Zootoca vivipara was found at two locations (Fig. 1), in the woodland area of Loborščak (N $\left.46.257177^{\circ}, \mathrm{E} 15.836866^{\circ}\right)$, near the settle-

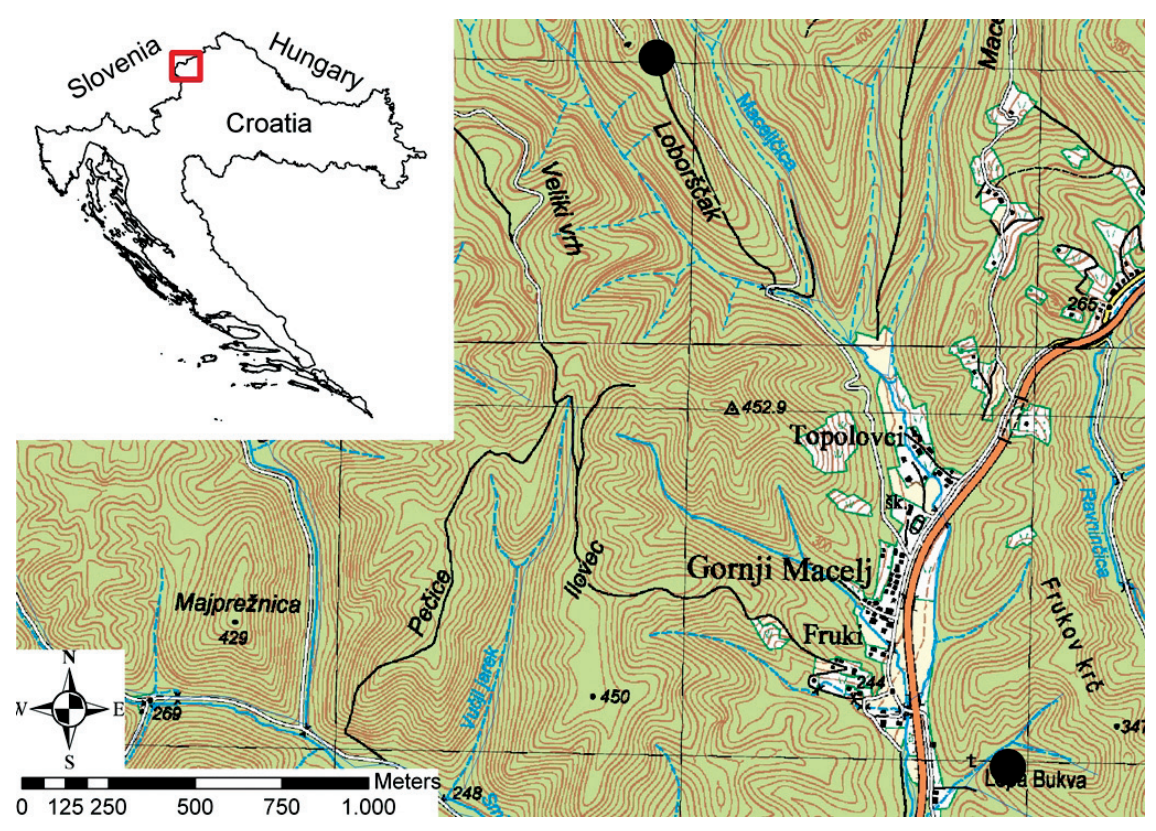

Fig. 1. Research area on Macelj Mountain, with black spots representing records of Zootoca vivipara. 


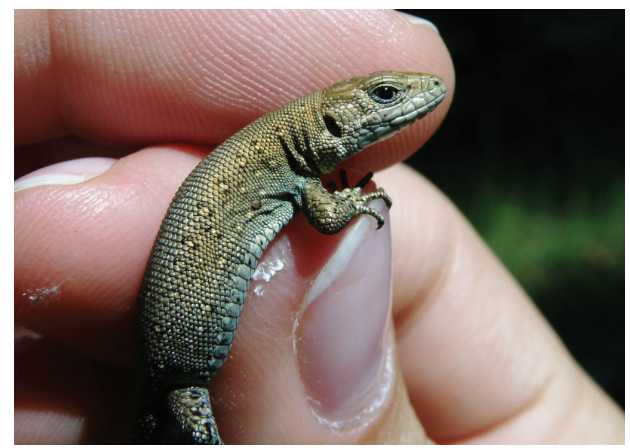

Fig. 2. Specimen of Zootoca vivipara from the Loborščak locality.

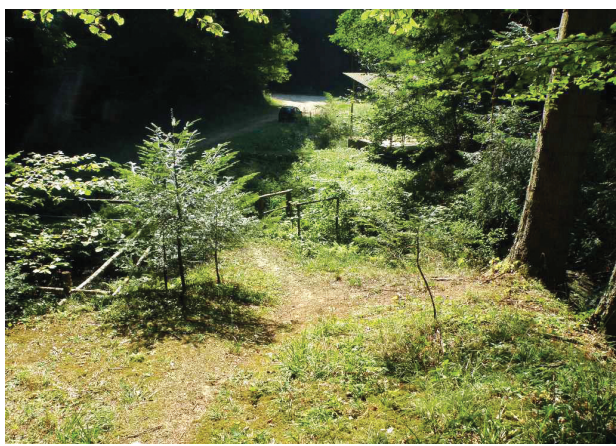

Fig. 3. Habitat of Zootoca vivipara at the Lepa Bukva record locality (222 m a.s.1.).

ment Gornji Macelj (three individuals, Fig. 2). This location is situated between 380-425 $\mathrm{m}$ a.s.l., in a forest dominated by beech and individual trees of chestnut and fir, and lower vegetation consisting of fern and small patches of grass. No other reptile species was recorded on the site. The Lepa Bukva location (N 46.238822 ${ }^{\circ}, \mathrm{E} 15.85024^{\circ}$ ), also near the settlement of Gornji Macelj, is a mixed forest of beech and fir, with a small grassy clearing, in the vicinity of a small creek (Fig. 3). Altitude range extends from 190 to 240 $\mathrm{m}$ a.s.l. On this site more than 30 individuals of the Common Wall Lizard Podarcis muralis and five specimens of Zootoca vivipara were observed.

The populations of $Z$. vivipara in Croatia and Slovenia are expected to be cross-boundary connected, where the species inhabits mountain ranges that belong to the territories of both countries. Hence the confirmation of their presence on Macelj Mountain was not surprising, since the species was known from the Slovenian part (KROFEL et al., 2009). The closest known population of Z. vivipara in Croatia relative to the new locality at Macelj Mountain is located $70 \mathrm{~km}$ to the south-west on Mount Žumberak. This makes these new records the northernmost in Croatia the first for the Hrvatsko Zagorje region, and an important contribution to our knowledge about the species distribution.

Since the population on Mount Macelj is isolated from the closest population on Žumberak Mountain by an insurmountable distance, we can assume it is a closed population, which can represent a possible threat to its long-term survival. In order to be able to successfully manage the Mount Macelj population (and other populations of this species in general), it is highly advisable to conduct further research on its distribution, population status, habitat preference and quality, and risk assessment.

Research was conducted within the project "Water bodies, amphibians and reptiles of the Krapina-Zagorje County (Mountains Strahinjčica, Ivanščica, Macelj, Kuna Gora and Cesargradska Gora)" carried out by the Croatian Herpetological Society - Hyla from 2011 till 2012 (licence number UP/I-612-07/11-33/0342, URBROJ 532-08-01-01/1-11-02, from March $\left.18^{\text {th }}, 2011\right)$.

Received October 30, 2015

\section{REFERENCES}

Agasyan, A., Avci, A., Tuniyev, B., Crnobrnja Isailovic, J., Lymberakis, P., Andrén, Cogalniceanu, D., Wilkinson, J., Ananjeva, N., Üzüm, N., Orlov, N., Podloucky, R., Tuniyev, S., Kaya, U., Böhme, W., 
Nettmann, H.K., Joger, U., Cheylan, M., Pérez-Mellado, V., BorczyK, B., Sterijovski, B., WestersтRöм, A. \& SснміDт B., 2010: Zootoca vivipara. The IUCN Red List of Threatened Species 2010: e. T61741A12552141. Downloaded on $2^{\text {th }}$ October 2015.

Anonymous, 2015a: Internet edition of the Croatian Encyclopedia. Leksikografski zavod Miroslav Krleža, Zagreb (http://www.enciklopedija.hr) [Last access: October $3^{\text {rd }}, 2015$ )

AnonYmous, 2015b: CRO Habitats - Republic of Croatia database of habitat types. DZZP, Zagreb (http:// www.crohabitats.hr) [Last access: October $3^{\text {rd }}, 2015$ )

BAŠKIERA, S., 2013: Reproductive characteristics of the viviparous lizard (Zootoca vivipara, Lichtenstein). Graduate thesis, Department of Biology, Faculty of Science, University of Zagreb, Zagreb, $50 \mathrm{pp}$.

BAŠKIERA, S. \& JeLIĆ, D., 2013: A comparative analysis of reproductive traits in viviparous and ovoviviparous populations of Zootoca vivipara (Von Jacquin, 1787). In: ŽAGAR, A. (Eds.), Book of Abstracts of 8th International symposium on the lacertids of the Mediterranean Basin. Societas herpetologica slovenica, Koper, Slovenia, p. 49.

CERovečKI, Z., 2002: Numerical determination of climatic and edaphic factors of the habitats in forest phytocoenosis of the Maceljsko Gorje Mountains. Šumarski list 126(1-2), 11-22.

Cornetti, L., Menegon, M., Giovine, G., Heulin, B. \& Vernesi, C., 2014: Mitochondrial and nuclear DNA survey of Zootoca vivipara across the eastern Italian Alps: evolutionary relationships, historical demography and conservation implications. PLOS ONE 9(1), e85912.

Dely O. G. \& Böнme W., 1984: Lacerta vivipara Jacquin 1787 - Waldeidechse. In: BöHme W. (eds.) Handbuch der Reptilien und Amphibien Europas. Band 2/I, Echsen (Sauria) II, (Lacertidae II: Lacerta). Wiesbaden, Aula-Verlag, p. 362-393.

Heulin, B., Guillaume, C. P., Vogrinc, N., Surget-Groba, Y. \& Tadić, Z., 2000: Further evidence of the existence of oviparous populations of Lacerta (Zootoca) vivipara in the NW of the Balkan Peninsula. Population biology 323, 461-468.

Jelić, D., Kuljerić, M., Koren, T., Treer, D., Šalamon, D., Lončar, M., Podnar-Lešić, M., Janev-Hutinec, B., Bogdanović, T. \& Mekinić, S., 2012: Red book of amphibians and reptiles of Croatia. Ministarstvo zaštite okoliša i prirode, Državni zavod za zaštitu prirode. Zagreb. 232 pp.

JeLIć, D., 2014: Checklist of Croatian amphibians and reptiles with bibliography of 250 years of research. Natura Sloveniae 16(2), 17-72.

Krofel, M., Cafuta, V., Planinc, G., Sopotnik, M., Šalamun, A., Tome, S., Vamberger, M. \& Žagar, A., 2009: Distribution of reptiles in Slovenia: a review of data collected until 2009. Natura Sloveniae 11(2), 61-99.

TAdej, N., Slovenec, D. TišLJAR, J. \& INKREt, I., 1997: Glauconitic materials from Lower Miocene Maceljsandstones of the Hrvatsko Zagorje, north-western Croatia. Geologia Croatica 50/1, 17-25.

\title{
SAŽETAK \\ Novi nalazi živorodne gušterice Zootoca vivipara (Lichtenstein, 1823) na Maceljskoj gori, najsjevernijem području njene rasprostranjenosti u Hrvatskoj
}

\author{
B. Lauš
}

Za živorodnu guštericu u Hrvatskoj postoje literaturni navodi još od 1854. godine nadalje, međutim nikada nisu provedena sistematična istraživanja i naša sadašnja saznanja o njenoj distribuciji i stanju populacija su relativno oskudna. Tokom istraživanja vodozemaca i gmazova Krapinsko-zagorske županije zabilježeno je nekoliko jedinki vrste Zootoca vivipara na dvije lokacije, po prvi puta na Maceljskoj gori. Najbliža poznata populacija u Hrvatskoj nalazi se na Žumberačkoj gori, oko $70 \mathrm{~km}$ prema jugozapadu. Ovi nalazi predstavljaju prve podatke o ovoj vrsti u regiji Hrvatsko zagorje i pomiču poznatu distribuciju prema sjeveru.

S obzirom da je živorodna gušterica klasificirana kao vrsta s nedovoljno podataka (DD) u Crvenoj knjizi vodozemaca i gmazova Hrvatske, novi podaci će pomoći u boljem razumijevanju njene distribucije i preferencije staništa. 